\title{
Editorial: Information Technology Dissonance
}

I sit here composing this editorial on a day (August 20) when the temperature may reach 100 degrees Fahrenheit (dry heat, thank you) for an issue that will reach my mailbox on a day when snow may well be piled halfway up its post. The dissonance may affect what I am about to write. If not, I'll have to discard this piece and conjure a new one.

I assume many of you have long since read the July 2005 College and Research Libraries article by Nisonger and Davis that replicated the 1985 Kohl-Davis study comparing the perceptions of LIS deans and ARL library directors of the importance of library and information science journals. As the ITAL Editorial Board and I already knew, our journal is perceived to be more important to practitioners than it is to LIS faculty-increasingly more so as the latest study shows. ${ }^{1}$ I have already addressed this dissonance in my inaugural editorial in the March 2005 issue. Our goal is to increase the value of our journal to all who are interested in library and information technology.

Despite the proliferation and popularity of blogs, wikis, RSS feeds, and slugs, in my working life I still receive most of my outside information from such old-fashioned sources as electronic lists (for example, lita-1), journal and newspaper articles (both print and electronic), Web sites, and by talking to colleagues, vendors, and "experts" face-to-face, by phone, or through e-mail. I love being editor of ITAL because I get to read the submissions before anyone else, except the authors. Our acceptance rate has been less than 50 percent since my term began, but I have learned something useful from every manuscript I have received. (I write this using Microsoft Word 2003, part of the standard edition for students and teachers. Its spellchecker doesn't like blogs or wikis. But that's another story.)

I don't think I'm a Luddite. (Microsoft Word doesn't think I am one either because it doesn't know any more about Luddites than it does about blogs and wikis. But, again, that's another story.) I am a library systems administrator, but I doubt that is relevant. A colleague of mine here at Washington State University (WSU) is associate vice president and general manager of edu-

John Webb (jwebb@wsu.edu) is Assistant Director for Digital Services/Collections, Washington State University Libraries, Pullman, and Editor of Information Technology and Libraries. cational telecommunications and technology, and his blog, Technology360, is one year old. I just checked it, picked randomly from among its categories, and found an entry dated today. Some of the techs in my department consult blogs regularly, and many of the librarians at WSU regularly use wikis to collaborate.

Rather, I think I'm probably typical. I have built a "library" of information sources that seem to stand me in good stead, and more good sources are not necessarily a good thing. Another colleague of mine in the WSU Center for Teaching and Learning has a library of sources that are heavily weighted toward blogs.

The growing richness of information sources may be a cacophony, but that simply means that staying informed in our field allows each of us to choose the sources that work best for us. Were I not planning to attend the LITA National Forum in San Jose from September 29 to October 2, the LITA bloggers would be on one of my computer screens all day during the forum. (Microsoft Word doesn't like the past subjunctive in my previous sentence, and it still doesn't like bloggers. But that's another story, too.)

An article in today's Washington Post (washingtonpost .com) by Robert MacMillan in his "Random Access" column titled "A Blog by Any Other Name ... " (August $25,2005)$ makes an even more interesting point. One reader wrote to him, "I really like reading your blog." MacMillan replied: "There must be some mistake, I thought, 'Random Access' is a column." He continued that "a column or a blog is in the eye of the reader." "I have a blog, a column, a daily article, a story ... " (The ellipses are his in both the title of the column and the preceding sentence.) "To me it's all the same. Some days this column comments on news that shows up in other publications. On others, all the reporting is my own. Sometimes, like today, I dispense with the reporting and just ramble."

I wish I had said that at the beginning of this piece, and that's not another story.

\section{Reference}

1. Thomas E. Nisonger and Charles Davis, "The Perception of Library and Information Science Journals by LIS Education Deans and ARL Library Directors: A Replication of the KohlDavis Study," College and Research Libraries 66, no. 4 (July 2005): 341-77. 